\section{JAUNDICE IN A CHILD WITH LEUKEMIA}

Clinical Problem: A 13 years old child presented with fever for 15 days along with jaundice. He was admitted in a hospital and detected to have pancytopenia. His Hepatitis A, B and E markers were negative. He underwent a bone marrow examination and was detected to acute lymphoblastic leukemia. He was started on steroids but the jaundice increased. His bilirubin increased from $14 \mathrm{mg} / \mathrm{dl}$ to $25 \mathrm{mg} / \mathrm{dl}$ with a direct bilirubin of $16 \mathrm{mg} / \mathrm{dl}$. His SGOT and SGPT were marginally elevated 110 and $130 \mathrm{mg} / \mathrm{dl}$ and total proteins and albumin were normal. Alkaline phosphatase was elevated. His stool was not clay coloured and there was no itching. Ultrasound abdomen showed hepatomegaly and Doppler of portal system was normal. His serum ferritin was 550 though fibrinogen and triglycerides were normal.

\section{What is the cause of jaundice in this child?}

Expert Opinion : Children with acute Iymphoblastic leukemia (ALL) frequently present with hepatomegaly and mild liver functional impairment. Severe jaundice is a rare complication of leukemia. Jaundice could be due to liver damage due to drugs, viral infections, tumour cell infiltrations and hemolysis. In this child, since viral markers were negative and the child already had jaundice prior to start of chemotherapy, the most likely cause of jaundice in this patient is leukemic infiltration of the hepatic sinusoids. Since this child had thrombocytopenia, a transjugular liver biopsy was done and histopathology showed leukemic infiltration of the liver.

DOI : 10.7199/ped. oncall.2014.5

Quick Response Code

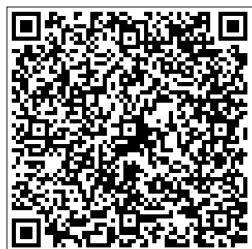

\section{TACHYARRHYTHMIA IN A CONGENITAL HEART DISEASE}

Clinical Problem : A 6 months old boy presented in the emergency with excessive crying. He had cough, cold for 2 days and received some medications for the same. There was no fever. On examination, he had a heart rate of $190 / \mathrm{min}$. There was no cardiomegaly, basal crepts or hepatomegaly. Blood pressure was on the higher range of normal for his age. An ECG showed sinus tachycardia. The tachycardia disappeared in next 12 hours without intervention following which excessive crying disappeared. Subsequently a train in tunnel murmur was heard over the precordium. An echocardiography was done that showed patent ductusarteriosus (PDA).

\section{Why did this child present with tacharrhythmia} as presentation of PDA?

Expert Opinion : On enquiry, the mother got the medicine that the child was getting for cough and cold. The child had received an oral syrup containing phenylephrine hydrochloride $5 \mathrm{mg}$ and chlorpheniramine maleate. Phenylephrine is a selective a1-adrenergic receptor agonist used primarily as a decongestant. The primary side effect of phenylephrine is hypertension. Because this medication is a sympathomimetic amine, it can also increase contractility force and increase output to the cardiac muscle. In other words, phenylephrine mimics norepinephrine binding to a-adrenoreceptors and can cause increased heart rate.

Ideally, no cough syrups are recommended in children less than 2 years of age due to their side effects.

DOI No. : $10.7199 /$ ped. oncall.2014.4

Quick Response Code

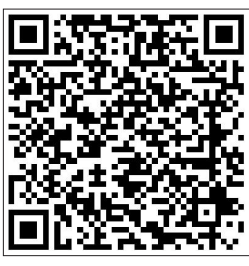

\section{BILIOUS ASCITES}

Clinical Problem: A 6 months old girl presented with diarrhea and vomiting for 10 days and abdominal distension for 1 day. There was no edema elsewhere. There is history of clay stools. On examination, she was jaundiced and had ascites. Investigations showed:

- Hemoglobin $=9.3 \mathrm{gm} / \mathrm{dl}$

- White cell count $=25,800$ cells $/$ cumm

- Platelets $=4,16,000$ cells $/$ cumm

- Bilirubin $=12 \mathrm{mg} / \mathrm{dl}($ direct $=5.2 \mathrm{mg} / \mathrm{dl}), \mathrm{SGOT}=$ $56 \mathrm{IU} / \mathrm{L}, \mathrm{SGPT}=45 \mathrm{IU} / \mathrm{L}$, total proteins $=3.2 \mathrm{gm} /$ $\mathrm{dl}$, albumin $=1.8 \mathrm{gm} / \mathrm{dl}$ and prothrombin time $=$ $12.6 \mathrm{sec}, \mathrm{PTT}=22.8 \mathrm{sec}$.

- Ascitic tap- bilious

- USG Abdomen - Hepatosplenomegaly with ascites.

\section{What is the cause of bilious ascites?}

Expert Opinion : This child had clay stools and direct jaundice with near normal liver enzymes suggestive of obstructive jaundice. Ultrasound abdomen has not shown any obstruction. However presence of bile in the peritoneum is suggestive of biliary leak. The 
commonest cause of biliary ascites is perforation in the common bile duct which could be due to trauma, infection or idiopathic. In this child, since there was diarrhea it is likely the infection predisposed to perforation. Perforation usually occurs in a weak wall and most likely cause of perforation should be choledochal cyst. On operation, it was found to be perforated choledochal cyst.

DOI : $10.7199 /$ ped.

oncall.2014.6

Quick Response Code
From: Medical Sciences Department, Pediatric Oncall, Mumbai.

Address for Correspondence Dr Ira Shah, 1/B Saguna, 271, B St Francis Road, Vile Parle (W), Mumbai 400056. 